\title{
Short Communication: Carnobacterium maltaromaticum: The Only Carnobacterium Species in French Ripened Soft Cheeses as Revealed by Polymerase Chain Reaction Detection
}

\author{
C. Cailliez-Grimal, ${ }^{*} \dagger^{1}$ H. C. Edima, ${ }^{*}$ A.-M. Revol-Junelles, ${ }^{*}$ and J.-B. Millière ${ }^{*} \dagger$ \\ *Nancy-Université, Laboratoire de Science et Génie Alimentaires (LSGA), Ecole Nationale Supérieure d'Agronomie et des Industries \\ Alimentaires-Institut National Polytechnique de Lorraine (ENSAIA-INPL), 2, Avenue de la Forêt de Haye, BP 172, F-54505, \\ Vandoeuvre-lès-Nancy Cedex, France \\ †Institut Universitaire de Technologie (IUT) Nancy-Brabois, Le Montet, F-54600 Villers-lès-Nancy, France
}

\begin{abstract}
The PCR technique using Cb1-Cb2R and species-specific primers was applied to various French soft flowered or washed rind cheeses to identify Carnobacterium species. Thirty cheeses made from cow's, ewe's, or goat's milk (raw or pasteurized), of which 20 were Appellation d'Origine Contrôlée, were analyzed in the autumn and spring. The results revealed that, irrespective of the season, the Carnobacterium genus was initially detected in 5 cheeses and was detected in 5 others after an enrichment period. Polymerase chain reaction results using species-specific primers of Carnobacterium showed that these 10 cheeses contained only the species Carnobacterium maltaromaticum. Six different patterns of fermentation were found, and 3 of the 10 cheeses contained C. maltaromaticum isolates with anti-Listeria activity.
\end{abstract}

Key words: Carnobacterium, polymerase chain reaction, French soft cheese

In the manufacture of soft cheeses, lactic acid bacteria are involved in all phases of cheese making. Initially present as natural microbiota or added as starter cultures, they actively participate in the development of flavor and texture in a wide range of cheeses (Giraffa, 2004; Marilley and Casey, 2004). Carnobacterium is a lactic acid bacterium that is not used as a starter because of its nonaciduric and psychrotrophic properties. Indeed, it cannot participate actively in the first phase of fermentation, but its growth can be induced during ripening as $\mathrm{pH}$ values increase and after a cold-storage period. Studies have shown that the Carnobacterium genus is predominant in French surface-mold-ripened soft Brie cheeses (Millière et al., 1994; Millière and Lefebvre, 1994). This genus has frequently been associ-

Received February 22, 2006.

Accepted October 21, 2006.

${ }^{1}$ Corresponding author: catherine.cailliez@ensaia.inpl-nancy.fr ated with the spoilage of seafood and meat products (Pilet et al., 1994; Connil et al., 1998; Paludan-Muller et al., 1998; Dalgaard et al., 2003). However, the bacteriocin-production ability of Carnobacterium genus may be considered useful in preventing the growth of foodborne pathogens such as Listeria (Duffes et al., 1999; Brillet et al., 2005; Laursen et al., 2005).

The aim of this work was to determine whether Carnobacterium is a ubiquitous genus present in many traditional soft cheeses and whether a diversity of species exists. Samples were taken from cheeses manufactured from cow's, goat's, and ewe's milk (raw or pasteurized) in different French provinces during 2 periods of the year. A previous study showed that genus-specific primers could be applied for the detection of this genus in cheeses (Cailliez-Grimal et al., 2005). Species-specific primers (Rachman et al., 2004) were then tested and applied to the cheese samples.

Strains were purchased from different collections (Table 1) and were maintained at $-20^{\circ} \mathrm{C}$ in $15 \%$ (vol/ vol) glycerol. They were subcultured in trypticase-soy medium (TS; Biomerieux, Craponne, France) supplemented with $0.6 \%$ (wt/vol) yeast extract (YE; Biokar Diagnostics, Beauvais, France) and incubated at their optimal growth temperature (Table 1).

Thirty cheeses, manufactured in France and purchased from a local supermarket in October 2004 and April 2005 (Table 2), were analyzed and their Carnobacterium flora enumerated by plate count and by PCR (see below). Fractions (10 g) of whole cheese (surface and interior) were homogenized in $90 \mathrm{~mL}$ of citrate buffer (0.5 $M, \mathrm{pH} 7.0)$. The whole suspension was submitted to a serial decimal dilution. Improvements in the detection of Carnobacterium spp. from cheese can be obtained on nonselective media (TS-YE agar or broth) with high $\mathrm{pH}$ values ( $\mathrm{pH}$ 9; Holzapfel, 1992) supplemented with $40 \mathrm{mg} / \mathrm{L}$ of nalidixic acid (Sigma, St. Louis, MO) and $5 \mathrm{mg} / \mathrm{L}$ of amphotericin (Sigma) and incubated under psychrotrophic conditions $\left(\right.$ at $7^{\circ} \mathrm{C}$ for $10 \mathrm{~d}$ ). For the plate count method, each serial decimal dilution was plated using spiral plating (Whitley Auto- 
Table 1. Strains used in this study ${ }^{1}$

\begin{tabular}{llc}
\hline Bacterial species & \multicolumn{1}{c}{$\begin{array}{c}\text { Strain } \\
\text { designation }\end{array}$} & $\begin{array}{c}\text { Growth } \\
\text { temperature, }{ }^{\circ} \mathrm{C}\end{array}$ \\
\hline Carnobacterium alterfunditum & CIP 105796 & 20 \\
Carnobacterium divergens & DSM $20624^{\mathrm{T}}$ & 30 \\
Carnobacterium funditum & CIP106503 & 22 \\
Carnobacterium gallinarum & DSM $4847^{\mathrm{T}}$ & 30 \\
Carnobacterium inhibens & CIP 106863 & 37 \\
Carnobacterium maltaromaticum & DSM $20730^{\mathrm{T}}$ & 30 \\
C. maltaromaticum & LMA 28 & 30 \\
Carnobacterium mobile & DSM $4848^{\mathrm{T}}$ & 30 \\
Carnobacterium viridans & CIP 107728 & 25 \\
\hline
\end{tabular}

${ }^{1} \mathrm{CIP}=$ Collection de l'Institut Pasteur (Paris, France); DSMZ = Deutsche Sammlung von Mikro-Organismen und Zellkulturen (Braunschweig, Germany); LMA = Laboratoire de Microbiologie Alimentaire, ENSAIAINPL (Nancy, France); ${ }^{\mathrm{T}}=$ type strain.

matic Spiral Plater, WASP 2; AES Laboratoire, Bruz, France). For the enrichment method, $10 \mathrm{~g}$ of each cheese was mixed with $90 \mathrm{~mL}$ of TS-YE broth medium (described above). The interior $\mathrm{pH}$ of the cheese was measured with an electrode pHM210 standard $\mathrm{pH}$ meter (Radiometer Analytical, Villerbanne, France).

Five colonies from each cheese sample were collected randomly. Isolates were Gram stained and examined for cell morphology and catalase activity. The carbohydrate fermentation patterns were identified with API 50 CHL galleries (API System, Montalieu-Vercieu, France).

Template DNA was obtained by the boiling method (Yost and Nattress, 2000; De Medici et al., 2003). One isolated bacterial colony was picked from the modified TS-YE agar plates with a sterile toothpick and resuspended in $50 \mu \mathrm{L}$ of sterile ultrapure water (Easypure, RF; Fisher Bioblock, Illkirch, France). From the TS-YE broth culture, a volume of $50 \mu \mathrm{L}$ was centrifuged in a microcentrifuge at $8,000 \times g$ for $3 \mathrm{~min}$ and the cell pellet was resuspended in $100 \mu \mathrm{L}$ of sterile ultrapure water. These suspensions were boiled for $5 \mathrm{~min}$, and the cellular debris was then pelleted by centrifugation at 8,000 $\times g$ for $3 \mathrm{~min}$. Ten microliters of each supernatant was retained for the PCR reaction.

Fractions of whole cheese $(10 \mathrm{~g})$ were homogenized as described above. A 1,000-fold-diluted matrix was used for the PCR assay. For the enrichment method, $10 \mathrm{~g}$ of each cheese was mixed with $90 \mathrm{~mL}$ of enrichment medium, as described above. After $10 \mathrm{~d}$ at $7^{\circ} \mathrm{C}$, a 1,000 fold-diluted sample was used for PCR.

Deoxyribonucleic acid sequences of the primers (obtained from Eurogentec, Herstal, Belgium) are indicated in Table 3. The amplification was carried out in a thermal cycler iCycler System (Bio-Rad, Marnes-laCoquette, France). The reaction mixture $(50 \mu \mathrm{L})$ contained $25 \mu \mathrm{L}$ of the ready-to-use master mixes (Eurogentec) and $10 \mu \mathrm{L}$ of the sample (described below), completed to $50 \mu \mathrm{L}$ with sterile ultrapure water. The PCR program was as follows: $5 \mathrm{~min}$ at $95^{\circ} \mathrm{C}$ for primary DNA denaturation, followed by a series of 30 cycles, each of which comprised $30 \mathrm{~s}$ at $95^{\circ} \mathrm{C}$ (denaturation), $30 \mathrm{~s}$ at the corresponding annealing temperature (see Table 3 ), $30 \mathrm{~s}$ at $72^{\circ} \mathrm{C}$ (extension), and a 7-min final extension step at $72^{\circ} \mathrm{C}$. Products were stored at $4^{\circ} \mathrm{C}$ until analysis. Aliquots $(20 \mu \mathrm{L})$ of the amplified products were subjected to electrophoresis in 1.5\% (wt/vol) agarose gels (Agarose DNA grade; Euromedex, Souffelweyersheim, France) in TAE buffer ( $40 \mathrm{~m} M$ Tris acetate, $1 \mathrm{~m} M$ EDTA, $\mathrm{pH}$ 8.2). Gels were stained with ethidium bromide $(5 \mu \mathrm{g} / \mathrm{mL})$ and visualized under UV light (312 nm). A 100-bp DNA ladder polymer was used as a molecular mass marker (Eurogentec).

To test the production of antimicrobial compounds, $50 \mu \mathrm{L}$ of neutralized and pasteurized cell-free culture supernatant fluid of each isolate was tested for the ability to produce antagonistic substances against Listeria monocytogenes CIP 82110 by the agar well-diffusion method (Mayr-Hasting et al., 1972).

Among the 30 cheeses tested, only DNA extracted from 5 cheeses (Brique de Jussac, Petit Munster Val de Weiss, Petit Munster fermier, Camembert Réo, Epoisses) gave an amplicon of 340 bp with Carnobacterium genus-specific $\mathrm{Cb} 1-\mathrm{Cb} 2 \mathrm{R}$ primers. From these cheeses, after $10 \mathrm{~d}$ at $7^{\circ} \mathrm{C}$, the enumeration of plates showed population levels of Carnobacterium spp. $\geq 10^{5}$ cfu/g (Table 2). Colonies on modified TS-YE agar were nonpigmented, convex, circular, and smooth.

After the enrichment period, with the same primers Cb1-Cb2R, DNA extracted from 5 other cheeses [Pérail, Picodon, Petit Munster (Petits amis), Camembert Issigny, Petit Livarot] also gave one band of $340 \mathrm{bp}$ (Table 2 ). In this case, the amount of Carnobacterium was $\leq 10^{2}$ cfu/g.

With the species-specific primers, DNA extracted from these 10 cheeses showed a positive response with the C. maltaromaticum-specific primers Cpis-23S-7 (Figure 1A). With the 5 other species-specific primers, 
Table 2. Detection of Carnobacterium spp. in French cheeses by the culture method and PCR, using primers Cb1-Cb2R, directly on the homogenate or after enrichment ${ }^{1}$

\begin{tabular}{|c|c|c|c|c|c|c|c|}
\hline \multirow[b]{2}{*}{ Cheese (brand name) } & \multirow[b]{2}{*}{ Milk type } & \multirow[b]{2}{*}{$\begin{array}{c}\text { Ripening } \\
\text { time }\end{array}$} & \multirow[b]{2}{*}{ Department code } & \multirow[b]{2}{*}{$\begin{array}{c}\mathrm{pH} \\
( \pm 005)\end{array}$} & \\
\hline & & & & & $\begin{array}{l}\text { Direct } \\
\text { PCR }\end{array}$ & $\begin{array}{l}\text { On plate, } \\
\text { log cfu/g }\end{array}$ & $\begin{array}{l}\text { PCR after } \\
\text { enrichment }\end{array}$ \\
\hline Pérail (Lou Pérac) & Pasteurized ewe's & $2 \mathrm{wk}$ & Aveyron F 12.225.01 CEE & 7.10 & - & $<2$ & + \\
\hline Margalet (Monbrenac) & Pasteurized ewe's & 2 to $3 \mathrm{wk}$ & Aveyron F 12.299.20 CEE & 7.10 & - & $<2$ & - \\
\hline Brique de Jussac (Jussac) & Raw ewe's & $3 \mathrm{wk}$ & Haute-Loire F 43.162.02 CEE & 7.47 & + & $6.2 \pm 0.1$ & + \\
\hline Rocamadour (Patrimoine gourmand) ${ }^{2}$ & Raw goat's & 1 to $4 \mathrm{wk}$ & Lot F 46.177.01 CEE & 6.80 & - & $<2$ & - \\
\hline Crottin de Chavignol (Cora) ${ }^{2}$ & Raw goat's & $10 \mathrm{~d}$ & Cher F 18.194.50 CEE & 6.50 & - & $<2$ & - \\
\hline Cavet (Fermier) & Raw goat's & $2 \mathrm{wk}$ & Drôme F 26.114.01 CEE & 4.76 & - & $<2$ & - \\
\hline Picodon $(\text { Rians })^{2}$ & Raw goat's & 2 to $3 \mathrm{wk}$ & Drôme F 26.011.01 CEE & 6.80 & - & $<2$ & + \\
\hline Le Chèvre de caractère (Soignon) & Raw goat's & 2 to $3 \mathrm{wk}$ & Vienne F 86.092.01 CEE & 6.94 & - & $<2$ & - \\
\hline Sainte Maure (Soignon) ${ }^{2}$ & Raw goat's & 2 to $5 \mathrm{wk}$ & Deux-Sèvres F 79.276.01 CEE & 6.50 & - & $<2$ & - \\
\hline Coulommiers (Cœur de Lion) & Pasteurized cow's & $>4 \mathrm{wk}$ & Calvados F 14.762.01 CEE & 7.40 & - & $<2$ & - \\
\hline Coulommiers (Cora) & Pasteurized cow's & $>4 \mathrm{wk}$ & Ille et Vilaine F 35.239.01 CEE & 7.67 & - & $<2$ & - \\
\hline Brie $(\text { Cora })^{2}$ & Pasteurized cow's & $>4 \mathrm{wk}$ & Vosges F 88.115.01 CEE & 7.55 & _- & $<2$ & _- \\
\hline Petit Munster $(\text { Frech })^{2}$ & Pasteurized cow's & 6 to $8 \mathrm{wk}$ & Bas-Rhin F 67.216.01 CEE & 7.10 & - & $<2$ & - \\
\hline Petit Munster $(\text { Fermier })^{2}$ & Pasteurized cow's & 6 to $8 \mathrm{wk}$ & Haut-Rhin F 68.249.02 CEE & 7.05 & - & $<2$ & - \\
\hline Petit Munster (Petits amis) $)^{2}$ & Pasteurized cow's & 6 to $8 \mathrm{wk}$ & Haut-Rhin F 68.252.02 CEE & 7.10 & _ & $<2$ & + \\
\hline Petit Munster (Val de Weiss) ${ }^{2}$ & Pasteurized cow's & 6 to $8 \mathrm{wk}$ & Haut-Rhin F 68.175.01 CEE & 7.64 & + & $6.6 \pm 0.1$ & + \\
\hline Petit Munster (Fermier) $)^{2}$ & Raw cow's & 6 to $8 \mathrm{wk}$ & Bas-Rhin F 67.216.01 CEE & 7.10 & + & $7.3 \pm 0.1$ & + \\
\hline Banon de Chalais (Bourdin) & Raw cow's & $3 \mathrm{wk}$ & Isère F 38.559.01 CEE & 6.50 & _- & $<2$ & - \\
\hline Camembert de Normandie (Lanquetot) ${ }^{2}$ & Raw cow's & $>4 \mathrm{wk}$ & Calvados F 14.478.01 CEE & 6.69 & - & $<2$ & - \\
\hline Camembert de Normandie (Lepetit) ${ }^{2}$ & Raw cow's & $>4 \mathrm{wk}$ & Calvados F 14.422.01 CEE & 7.26 & _- & $<2$ & - \\
\hline Camembert de Normandie (Patrimoine gourmand $)^{2}$ & Raw cow's & $>4 \mathrm{wk}$ & Calvados F 14.342.01 CEE & 6.29 & _ & $<2$ & - \\
\hline Camembert de Normandie (Isigny Sainte Mère) $)^{2}$ & Raw cow's & $>4 \mathrm{wk}$ & Calvados F 14.342.01 CEE & 6.40 & - & $<2$ & + \\
\hline Camembert de Normandie $(\text { Réo })^{2}$ & Raw cow's & $>4 \mathrm{wk}$ & Manche F 50.267.01 CEE & 7.10 & + & $7.80 \pm 0.1$ & + \\
\hline Epoisses (Lincet) $^{2}$ & Raw cow's & $>4 \mathrm{wk}$ & Haute Marne F 52.092.01 CEE & 7.30 & + & $5.47 \pm 0.1$ & + \\
\hline Petit Pont-l'Evêque (Patrimoine gourmand) ${ }^{2}$ & Raw cow's & $>2 \mathrm{wk}$ & Calvados F 14.342.01 CEE & 7.40 & - & $<2$ & - \\
\hline Petit Livarot (Lanquetot) ${ }^{2}$ & Raw cow's & 1 to $2 \mathrm{mon}$ & Calvados F 14.478.01 CEE & 7.96 & - & $<2$ & + \\
\hline Langres (Germain) $)^{2}$ & Thermic cow's & 1 to $2 \mathrm{mon}$ & Haute Marne F 52.092.01 CEE & 6.80 & _- & $<2$ & - \\
\hline Chaource (Lanquetot) ${ }^{2}$ & Thermic cow's & $>2$ wk & Aube F 10.399.01 CEE & 7.13 & - & $<2$ & - \\
\hline Camembert biologique (Cora) & Thermic cow's & $>4 \mathrm{wk}$ & Morbihan F 56.179.01 CEE & 6.96 & - & $<2$ & - \\
\hline Camembert (Président) & Thermic cow's & $>4 \mathrm{wk}$ & Calvados F $14.162 .01 \mathrm{CEE}$ & 7.70 & _- & $<2$ & - \\
\hline
\end{tabular}

${ }^{1}$ Results as expressed as means of 3 measures ( \pm SD) of 3 samples purchased in October 2004 and in April 2005, and the data from October and April are computed together

${ }^{2} \mathrm{AOC}$ (Appellation d'Origine Contrôlée) cheese. 
Table 3. Oligonucleotides used for PCR amplification

\begin{tabular}{llcl}
\hline Primer & \multicolumn{1}{c}{ Sequence } & $\mathrm{T}_{m},{ }^{\circ} \mathrm{C}$ & \multicolumn{1}{c}{ Reference } \\
\hline Cb1 & 5'-CCG TCA GGG GAT GAG CAG TTA C-3' & 69 & Nissen et al. (1994) \\
Cb2R & 5'-ACA TTC GGA AAC GGA TGC TAA T-3' & 69 & Yost and Nattress (2000) \\
16S-2 & 5'-CTT GTA CAC ACC GCC CGT C-3' & 56 & Rachman et al. (2004) \\
23S-7 & 5'-GGT ACT TAG ATG TTT CAG TTC-3' & 56 & Rachman et al. (2004) \\
Cdiv & 5'-TTC TAA AAA AAT AGT ACT CTT G-3' & 56 & Rachman et al. (2004) \\
Cgal & 5'-TAG TTT CAC TCT AAA AAA AAC-3' & 56 & Rachman et al. (2004) \\
Cinh & 5'-TTT TAT TTG CAC AAA TA-3' & 50 & Rachman et al. (2004) \\
Cmob & 5'-CTC ATT TAA TTG CAC AAA AAG G-3' & 58 & Rachman et al. (2004) \\
Cpis & 5'-TTT ATT TTT AAT TAA ATA CCC-3' & 53 & Rachman et al. (2004) \\
Cvir & 5'-ATA AGT ATA AGA TGT TTT TT-3' & 53 & Rachman et al. (2004) \\
\hline
\end{tabular}

no response was obtained (example with the specificprimer of Carnobacterium divergens; Figure 1B).

Five colonies isolated from these 10 cheeses were picked and stained. They were rods that appeared singly, in pairs, or in short chains, and were gram positive and catalase negative. Cells were nonmotile and nonspore forming. They were tested by species-specific PCR and gave a response only with $C$. maltaromaticum-specific primers (data not shown).

A comparison of their biochemical characteristics is shown in Table 4. Among the 50 isolates from the 10 cheeses (5 colonies isolated from each positive cheese), results from the API $50 \mathrm{CHL}$ showed 6 differences in the fermentation patterns. All isolates were consistent in their ability to produce acid from the following substrates normally fermented by carnobacteria: $\beta$-gentiobiose, saccharose, $N$-acetyl glucosamine, amygdalin, arbutin, esculin, salicin, maltose, cellobiose, D-mannose, D-fructose, D-glucose, and ribose (Table 4).

Like other carnobacteria, isolates did not produce acid from the following: erythritol, D-arabinose, L-xylose, adonitol, $\beta$-methyl-xyloside, rhamnose, dulcitol, inulin, melezitose, D-raffinose, glycogen, xylitol, D-lyx- ose, D-fucose, L-fucose, D-arabitol, and L-arabitol (Table 4). Isolates from Camembert Réo (C. maltaromaticum reo), Epoisses (C. maltaromaticum epoisses), and Petit Munster (Petits amis; C. maltaromaticum amis) exhibited the same pattern, whereas Petit Munster (Fermier and Val de Weiss; C. maltaromaticum fermier and $C$. maltaromaticum weiss) and Isigny (C. maltaromaticum isigny) were identical. The other isolates, Pérail $(C$. maltaromaticum perail), Petit Livarot (C. maltaromaticum livarot), Brique de Jussac (C. maltaromaticum jussac) exhibited different patterns.

The ability to produce antagonistic substances against L. monocytogenes CIP 82110 was found with isolates from 3 different cheese samples, 1 from pasteurized ewe's milk (Pérail) and 2 from raw cow's milk (Réo and Epoisses). The diameter of inhibition against L. monocytogenes CIP 82110 for the 3 isolates tested was $19 \pm 1.0 \mathrm{~mm}$.

The primers Cb1-Cb2R were used successfully to conduct a rapid screening of the genus in a wide variety of soft French cheeses. Thirty cheeses of 19 types that differed in the methods used in manufacture and ripening were analyzed. The presence and the number of
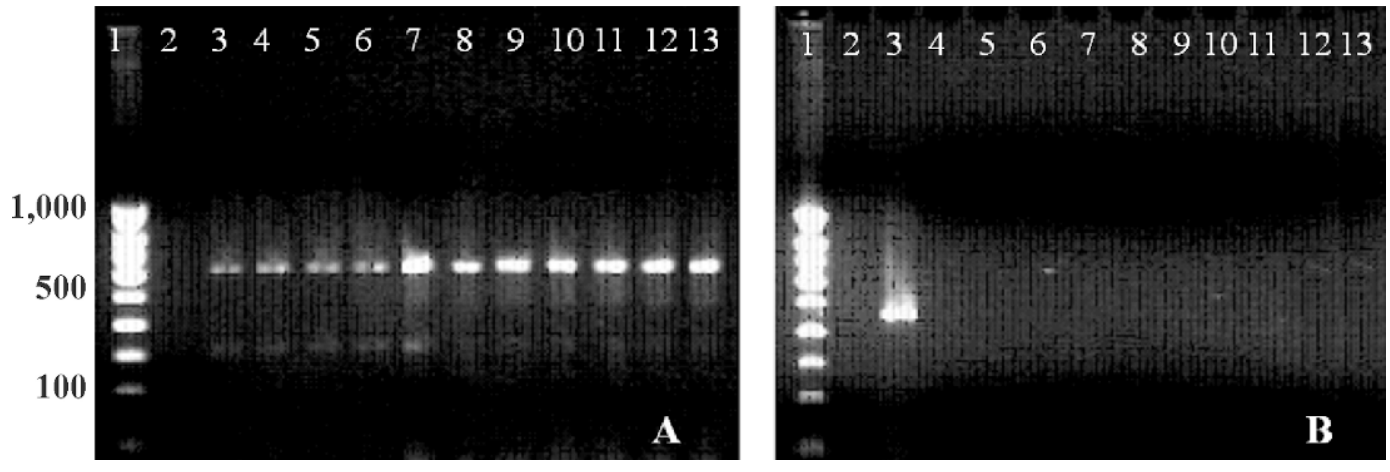

Figure 1. Electrophoresis in a 1.5\% agarose gel of PCR amplification products with primers (A) Cpis-23S-7 and (B) Cdiv-23S-7. Lanes for panels A and B are as follows: 1: 100 to 1,000 bp molecular weight ladder; 2: no template negative control; 3: Carnobacterium maltaromaticum LMA 28 (A) or Carnobacterium divergens DSM 20624 (B); 4: Pérail (Lou Pérac); 5: Brique de Jussac (Jussac); 6: Picodon (Rians); 7: Petit Munster (Petits amis); 8: Petit Munster (Val de Weiss); 9: Petit Munster (Fermier); 10: Camembert de Normandie (Isigny) 11: Camembert de Normandie (Réo); 12: Epoisses (Lincet); 13: Petit Livarot (Lanquetot). ${ }^{\mathrm{T}}=$ type strain. 
Table 4. Comparison of the characteristics of the Carnobacterium strains isolated from cheeses with those of Carnobacterium maltaromaticum ${ }^{1}$

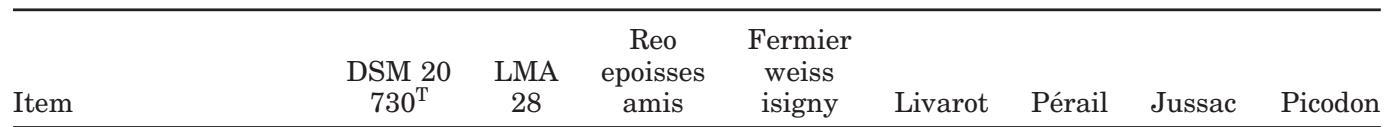

\begin{tabular}{|c|c|c|c|c|c|c|c|c|}
\hline Glycerol & + & + & $\mathrm{w}$ & - & $\mathrm{w}$ & + & - & - \\
\hline L-Ärabinose & - & - & - & + & - & - & - & $\mathrm{w}$ \\
\hline D-Xylose & - & - & - & + & - & - & - & + \\
\hline Galactose & - & $\mathrm{w}$ & - & + & + & - & + & $\mathrm{w}$ \\
\hline L-Sorbose & - & - & - & - & - & - & + & - \\
\hline Inositol & + & + & - & - & - & - & - & _- \\
\hline Mannitol & + & + & $\mathrm{w}$ & - & $\mathrm{w}$ & + & + & - \\
\hline Sorbitol & - & - & - & _- & $\mathrm{w}$ & - & $\mathrm{w}$ & _ \\
\hline$\alpha$-Methyl-D-mannoside & + & + & - & - & - & + & - & - \\
\hline$\alpha$-Methyl-D-glucoside & + & + & - & + & - & + & - & - \\
\hline Lactose & + & + & - & - & + & + & - & $\mathrm{w}$ \\
\hline Melibiose & - & - & - & + & - & - & + & - \\
\hline Trehalose & + & + & + & + & $\mathrm{w}$ & + & + & - \\
\hline Amidon & - & + & - & - & - & - & - & - \\
\hline D-Turanose & + & + & - & + & - & $\mathrm{w}$ & - & - \\
\hline D-Tagatose & - & - & - & - & + & - & + & - \\
\hline Gluconate & + & + & - & - & $\mathrm{w}$ & - & - & $\mathrm{w}$ \\
\hline
\end{tabular}

\begin{abstract}
${ }^{1}$ Results from 5 isolates of each cheese: Réo (C. maltaromaticum reo), Epoisses (C. maltaromaticum epoisses), Petit Munster (Petits amis; C. maltaromaticum amis), Petit Munster (Fermier; C. maltaromaticum fermier), Petit Munster (Val de Weiss, C. maltaromaticum weiss), Isigny (C. maltaromaticum isigny), Petit Livarot (C. maltaromaticum livarot), Pérail (C. maltaromaticum perail), Brique de Jussac (C. maltaromaticum jussac), Picodon (C. maltaromaticum picodon). Isolates produced acid from the following: $\beta$-gentiobiose, saccharose, $N$-acetyl glucosamine, amygdalin, arbutine, esculin, salicin, maltose, cellobiose, D-mannose, Dfructose, D-glucose, and ribose. Isolates did not produce acid from the following: erythritol, D-arabinose, Lxylose, adonitol, $\beta$-methyl-xyloside, rhamnose, dulcitol, inulin, melezitose, D-raffinose, glycogen, xylitol, Dlyxose, D-fucose, L-fucose, D-arabitol, L-arabitol. + = positive response; - = negative response; $\mathrm{w}=$ weak response.
\end{abstract}

Carnobacterium in these cheeses, between 1 and $10^{7}$ bacteria/g, were compatible with the amounts found previously (Millière et al., 1994; Millière and Lefebvre, 1994). This genus has been detected in cheeses manufactured in various departments in the East (Vosges, Bas-Rhin, Haute-Marne), in the West (Manche, Calvados), and in the South (Aveyron, Drôme, Haute-Loire) of France.

Ten positive samples with $\mathrm{Cb} 1-\mathrm{Cb} 2 \mathrm{R}$ primers were also positive with the species-specific primers of C. maltaromaticum. The other Carnobacterium species (except $C$. divergens) were isolated from others sources, so it was not surprising that they were absent from the cheese (Collins et al., 1987; Franzmann et al., 1991; Joborn et al., 1999; Holley et al., 2002; Pikuta et al., 2005). On the other hand, the detection of $C$. divergens, previously found in cheeses (Millière and Lefebvre, 1994; Morea et al., 1999) was expected.

A previous study showed Carnobacterium only in cow's milk cheese (Millière et al., 1994). In this work, ewe's and goat's milk cheeses also contained this genus. The $\mathrm{pH}$ values of cheeses tested varied from 5.6 to 8.1, which are in the $\mathrm{pH}$ range required for the growth of the genus Carnobacterium. No correlations were found among the ripening of cheese, use of raw or pasteurized milk, and C. maltaromaticum counts. Cheeses con- taining Carnobacterium did not differ significantly in taste or off-flavors from the same cheeses without Carnobacterium (Camembert, Munster). Eight cheeses were AOC cheeses, a designation that guarantees the quality of the product. The role of the Carnobacterium in these cheeses was therefore unclear.

Isolates from 3 different cheeses ( 1 from pasteurized ewe's milk, 2 from raw cow's milk) exhibited anti- $L$. monocytogenes activity. In raw milk soft cheese manufacturing, $L$. monocytogenes could be present at the end of the ripening period, with the rind being the preferential site of colonization. After food processing, this species can potentially grow in refrigerated products stored for extended periods. The anti-Listeria property of isolates from industrial cheeses should then be an advantage. Assuming that no product defect is related to the presence of Carnobacterium, it could be interesting to investigate their positive influence in the preservation of cheese.

\section{REFERENCES}

Brillet, A., M. F. Pilet, H. Prevost, M. Cardinal, and F. Leroi. 2005. Effect of inoculation of Carnobacterium divergens V41, a biopreservative strain against Listeria monocytogenes risk, on the microbiological, chemical and sensory quality of cold-smoked salmon. Int. J. Food Microbiol. 104:309-324. 
Cailliez-Grimal, C., R. Miguindou-Mabiala, M. Leseine, A. M. RevolJunelles, and J. B. Milliere. 2005. Quantitative polymerase chain reaction used for the rapid detection of Carnobacterium species from French soft cheeses. FEMS Microbiol. Lett. 250:163-169.

Collins, M. D., J. A. E. Farrow, B. A. Phillips, S. Ferusu, and D. Jones. 1987. Classification of Lactobacillus divergens, Lactobacillus piscicola, and some catalase-negative, asporogenous, rodshaped bacteria from poultry in a new genus Carnobacterium. Int. J. Syst. Bacteriol. 37:310-316.

Connil, N., X. Dousset, B. Onno, M. F. Pilet, M. F. Breuil, and M. C. Montel. 1998. Enumeration of Carnobacterium divergens V41, Carnobacterium piscicola V1 and Lactobacillus brevis LB62 by in situ hybridization-flow cytometry. Lett. Appl. Microbiol. 27:302-306

Dalgaard, P., M. Vancanneyt, N. Euras Vilalta, J. Swings, P Fruekilde, and J. J. Leisner. 2003. Identification of lactic acid bacteria from spoilage associations of cooked and brined shrimps stored under modified atmosphere between $0^{\circ} \mathrm{C}$ and $25^{\circ} \mathrm{C}$. J. Appl. Microbiol. 94:80-89.

De Medici, D., L. Croci, E. Delibato, S. Di Pasquale, E. Filetici, and L. Toti. 2003. Evaluation of DNA extraction methods for use in combination with SYBR Green I real-time PCR to detect Salmonella enterica serotype enteritidis in poultry. Appl. Environ. Microbiol. 69:3456-3461.

Duffes, F., F. Leroi, P. Boyaval, and X. Dousset. 1999. Inhibition of Listeria monocytogenes by Carnobacterium spp. strains in a simulated cold smoked fish system stored at $4^{\circ} \mathrm{C}$. Int. J. Food Microbiol. 47:33-42.

Franzmann, P. D., P. Hopfl, N. Weiss, and B. J. Tindall. 1991. Psychrotrophic, lactic acid-producing bacteria from anoxic waters in Ace Lake, Antarctica: Carnobacterium funditum sp. nov. and Carnobacterium alterfunditum sp. nov. Arch. Microbiol. 156:255-262.

Giraffa, G. 2004. Studying the dynamics of microbial populations during food fermentation. FEMS Microbiol. Rev. 28:251-260.

Holley, R. A., T. Y. Guan, M. Peirson, and C. K. Yost. 2002. Carnobacterium viridans sp. nov., an alkaliphilic, facultative anaerobe isolated from refrigerated, vacuum-packed bologna sausage. Int. J. Syst. Evol. Microbiol. 52:1881-1885.

Holzapfel, W. H. 1992. Culture media for non-sporulating gram-positive food spoilage bacteria. Int. J. Food Microbiol. 17:113-133.

Joborn, A., M. Dorsch, J. C. Olsson, A. Westerdahl, and S. Kjelleberg. 1999. Carnobacterium inhibens sp. nov., isolated from the intestine of Atlantic salmon (Salmo salar). Int. J. Syst. Bacteriol. 49:1891-1898.
Laursen, B. G., L. Bay, I. Cleenwerck, M. Vancanneyt, J. Swings, P. Dalgaard, and J. J. Leisner. 2005. Carnobacterium divergens and Carnobacterium maltaromaticum as spoilers or protective cultures in meat and seafood: Phenotypic and genotypic characterization. Syst. Appl. Microbiol. 28:151-164.

Marilley, L., and M. G. Casey. 2004. Flavours of cheese products: Metabolic pathways, analytical tools and identification of producing strains. Int. J. Food Microbiol. 90:139-159.

Mayr-Hasting, A., A. J. Hedges, and R. C. M. Berkeley. 1972. Methods for studying bacteriocins. Vol. 7A. Pages 315-422 in Methods in Microbiology. Academic Press, New York, NY.

Millière, J. B., and G. Lefebvre. 1994. Carnobacterium piscicola, a common species of French soft cheeses from cow's raw milk. Neth. Milk Dairy J. 48:19-30.

Millière, J. B., M. Michel, F. Mathieu, and G. Lefebvre. 1994. Presence of Carnobacterium spp. in French surface mould-ripened softcheese. J. Appl. Bacteriol. 76:264-269.

Morea, M., F. Baruzzi, and P. S. Cocconcelli. 1999. Molecular and physiological characterization of dominant bacterial populations in traditional Mozzarella cheese processing. J. Appl. Microbiol. $87: 574-582$.

Nissen, H., A. Holck, and R. H. Dainty. 1994. Identification of Carnobacterium spp. and Leuconostoc spp. in meat by genus-specific 16S rRNA probes. Lett. Appl. Microbiol. 19:165-168.

Paludan-Muller, C., P. Dalgaard, H. H. Huss, and L. Gram. 1998. Evaluation of the role of Carnobacterium piscicola in spoilage of vacuum- and modified-atmosphere-packed cold-smoked salmon stored at $5^{\circ}$ C. Int. J. Food Microbiol. 39:155-166.

Pikuta, E. V., D. Marsic, A. Bej, J. Tang, P. Krader, and R. B. Hoover. 2005. Carnobacterium pleistocenium sp. nov., a novel psychrotolerant, facultative anaerobe isolated from permafrost of the Fox Tunnel in Alaska. Int. J. Syst. Evol. Microbiol. 55:473-478.

Pilet, M. F., X. Dousset, R. Barré, G. Novel, M. Desmazeaud, and J. C. Piard. 1994. Evidence for two bacteriocins produced by Carnobacterium piscicola and Carnobacterium divergens isolated from fish and active against Listeria monocytogenes. J. Food Prot. 58:256-262.

Rachman, C., P. Kabadjova, R. Valcheva, H. Prevost, and X. Dousset. 2004. Identification of Carnobacterium species by restriction fragment length polymorphism of the 16S-23S rRNA gene intergenic spacer region and species-specific PCR. Appl. Environ. Microbiol. 70:4468-4477.

Yost, C. K., and F. M. Nattress. 2000. The use of multiplex PCR reactions to characterize populations of lactic acid bacteria associated with meat spoilage. Lett. Appl. Microbiol. 31:129-133. 